LETTERS

\title{
Experience with infliximab (anti-TNF $\alpha$ monoclonal antibody) as monotherapy for giant cell arteritis
}

A P Andonopoulos, N Meimaris, D Daoussis, A Bounas, G Giannopoulos

C orticosteroids have been the mainstay of treatment for giant cell arteritis (GCA), usually given for at least two years, with the potential for unpleasant consequences. $^{12}$ Infliximab, a chimeric monoclonal antibody against tumour necrosis factor $\alpha$ (TNF $\alpha)$, used successfully in the treatment of rheumatoid arthritis (RA) and other conditions, $^{3-5}$ was considered by us, on the basis of pathogenic and pathologic data of GCA, as a potentially effective treatment for this disease. Consequently, we decided to try it in two of our patients with GCA, without concomitant administration of corticosteroids, hoping that if only a few infusions of anti-TNF $\alpha$ cured the disease then the side effects of chronic steroid treatment might be avoided.

Our patients were both male, 85 and 80 years old, respectively, seen six months apart from each other. They had a typical clinical picture of GCA with recent onset of fatigue, weight loss, bilateral temporal headache and low grade fever, mild anaemia, erythrocyte sedimentation rate $\left(\right.$ ESR) $>100 \mathrm{~mm} / \mathrm{l}^{\mathrm{st}} \mathrm{h}$ and $\mathrm{C}$ reactive protein $(\mathrm{CRP})>10$ times normal. A temporal artery biopsy was typical for GCA. After approval by the hospital ethics committee and informed consent from the patients, $3 \mathrm{mg} / \mathrm{kg}$ of infliximab were given intravenously. Within hours the patients reported dramatic improvement, and their fever and headache disappeared. A second infusion was given after two weeks when the ESR was around $40 \mathrm{~mm} / \mathrm{s}^{\mathrm{st}} \mathrm{h}$ and, and a third, one month later when the patients were in excellent condition and had a normal ESR and CRP.

The first patient did well for three months, but at that time symptoms recurred and, despite two infusions at monthly intervals, no significant improvement was noted. Consequently, a decision to stop infliximab was made, and methylprednisolone $16 \mathrm{mg} /$ day was started, with excellent response. He was followed up closely.

Symptoms and a rise in the ESR recurred six weeks after the third injection in the second patient. With the experience of the first patient, we decided to stop infliximab and switch the patient to the conventional treatment, giving methylprednisolone $32 \mathrm{mg} /$ day. He responded well and his ESR was $22 \mathrm{~mm} / \mathrm{l}^{\text {st }} \mathrm{h}$ three weeks later. He was then followed up regularly.

As described above, infliximab as monotherapy was extremely effective at the beginning of the treatment of our patients. A favourable response of GCA to this agent was not unexpected. TNF $\alpha$ has been found, in the pathological lesions of GCA. ${ }^{6}$ Furthermore, the pathology of the lesions, with the local accumulation of CD4 $(+)$ memory cells, resembles that of RA, for which anti-TNF $\alpha$ is very effective. Finally, an association between GCA with different TNF $\alpha$ microsatellite polymorphisms has been reported.

However, the initial dramatic response of our patients was not followed by a sustained improvement. It may very well be that large doses of infliximab, given monthly for a prolonged time, may be effective. However, such an approach is by no means cost effective, and should not be attempted. This trial was based on the hypothesis that, if three, or at the most, five infusions of infliximab, cured this dangerous but self limiting disease, it might be worth giving it, and avoiding the long term undesirable effects of the conventional approach. This was not found to be the case.

In a recent report infliximab was shown to be effective in three of four cases of GCA resistant to steroid. ${ }^{8}$ Furthermore, anti-TNF $\alpha$ treatment of a case of GCA resistant to steroids and immunosuppressive drugs has been reported. ${ }^{9}$

Consequently, we suggest that infliximab should be used in GCA only for patients who are unresponsive to, or intolerant of steroids and/or methotrexate. Probably, a larger dose than that used in RA given for relatively long time will be required. A further conclusion may be that TNF $\alpha$ is one of the major cytokines mediating inflammation in GCA.

\section{Authors' affiliations}

A P Andonopoulos, N Meimaris, D Daoussis, A Bounas,

G Giannopoulos, Department of Medicine, Division of Rheumatology, University of Patras School of Medicine, Patras, Greece

Correspondence to: A P Andonopoulos, Division of Rheumatology, University of Patras School of Medicine, 26500 Rio, Patras, Greece; andandon@med.upatras.gr

Accepted 5 March 2003

\section{REFERENCES}

1 Nesher G, Sonnenblick M, Friedlander Y. Analysis of steroid related complications and mortality in temporal arteritis: a 15-year survey of 43 patients. J Rheumatol 1994;21:1283-6.

2 Gabriel SE, Sunku J, Salvarani C, O'Fallon WM, Hunder GG. Adverse outcomes of anti-inflammatory therapy among patients with polymyalgia rheumatica. Arthritis Rheum 1997:40:1873-8.

3 Maini R, St Clair EW, Breedveld F, Furst D, Kalden J, Weisman M, et al. Infliximab (chimeric anti-fumor necrosis factor $\alpha$ monoclonal antibody) versus placebo in rheumatoid arthritis patients receiving concomitant methotrexate: a randomized phase III trial. Lancet 1999:354:1932-9.

4 Brandt J, Haibel H, Cornely D, Golder W, Gonzalez J, Reddig J, et al. Successful treatment of active ankylosing spondylitis with the anti-tumor necrosis factor $\alpha$ monoclonal antibody infliximab. Arthritis Rheum 2000:43: 1346-52

5 Sfikakis PP, Theodossiadis PG, Katsiari CG, Kaklamanis P, Markomichelakis NN. Effect of infliximab on sight-threatening panuveitis in Behçet's disease. Lancet 2001;358:295-6.

6 Field M, Cook A, Gallacher G. Immuno-localisation of tumour necrosis factor and its receptors in temporal arteritis. Rheumatol Int 1997; 17:113-18.

7 Mattey DL, Hajeer AH, Dababneh A, Thomson W, Gonzalez-Gay MA, Garcia-Porrua C, et al. Association of giant cell arteritis and polymyalgia rheumatica with different tumor necrosis factor microsatellite polymorphisms. Arthritis Rheum 2000;43:1749-55.

8 Cantini F, Niccoli L, Salvarani C, Padula A, Olivieri I. Treatment of longstanding active giant cell arteritis with infliximab: report of four cases. Arthritis Rheum 2001:44:2933-5.

9 Airo P, Antonioli CL, Vianelli M, Toniati P. Anti-tumour necrosis factor treatment with infliximab in a case of giant cell arteritis resistant to steroid and immunosuppressive drugs. Rheumatology (Oxford) 2002;41:347-9. 


\title{
Correlation between interleukin 10 gene promoter region polymorphisms and clinical manifestations in Japanese patients with Sjögren's syndrome
}

\author{
T Origuchi, E Kawasaki, A Ide, M Kamachi, F Tanaka, H Ida, A Kawakami, K Migita, K Eguchi
}

Ann Rheum Dis 2003;62:1117-1118

$\mathrm{S}$ jögren's syndrome (SS) is an autoimmune disease characterised by lymphocytic infiltration and glandular tissue dysfunction of exocrine glands such as the salivary and lachrymal glands in genetically susceptible people. Several cytokines, including interleukin 10 (IL10), have been proposed to have a role in the pathogenesis of the disease. Although the major genes involved in susceptibility to SS are within the major histocompatibility complex (MHC) region, several putative non-MHC genetic loci (Ro52, ${ }^{1}$ ILl, ${ }^{2}$ IL6, ${ }^{3}$ Fas/FasL, ${ }^{4}$ mannose binding lectin, ${ }^{56}$ TAP $2,{ }^{7}$ and glutathione S-transferase $\mathrm{Ml}$ gene $^{8}$ ) have been proposed as candidate genes. Recently, Hulkkonen et al reported that in Finnish patients the haplotypes formed on the basis of the IL10 gene alleles (at the -1082, -819, and -592 loci) were related to susceptibility to primary SS. ${ }^{\circ}$ However, no correlation between extraglandular symptoms and IL10 haplotypes was found in that study. In this study we analysed promoter region polymorphisms of the ILl0 gene in 47 Japanese patients with primary SS, and compared them with the values of several clinical and immunological variables.

The haplotype and genotype frequencies in Japanese subjects differed from those in white subjects. The GCC haplotype, which is predominant in white subjects, was less common in Japanese people. In contrast, the frequency of the ATA haplotype was significantly increased in Japanese subjects compared with white controls. The ACC haplotype carrier rate was significantly decreased in patients with SS compared with that in control subjects (34\% v 51\%, $\mathrm{p}=0.047$ ) (table 1). The frequency of the ACC haplotype was also decreased in patients with SS (18\% v 29\%). In contrast, the frequency of the ATA haplotype was increased in patients with SS compared with that in control subjects (73\% v 65\%). Further, we divided the patients with SS into a high s-IgG concentration group ( $\geqslant 15 \mathrm{~g} / \mathrm{l})$ and a normal s-IgG group ( $\mathrm{s}-\operatorname{Ig} \mathrm{G}<15 \mathrm{~g} / \mathrm{l}$ ) (table 1 ). The ATA/ATA genotype was significantly increased in the high s-IgG group $(61 \% \vee 11 \%$, $\mathrm{p}=0.012)$. The ATA haplotype frequency was also significantly increased in the high s-IgG group $(77 \% \vee 50 \%$, $p=0.033)$. In contrast, the ACC haplotype was decreased in the high s-IgG group ( $13 \%$ v 33\%).

Next, we compared the mean age at onset among genotypes of the IL10 gene in patients with SS (fig 1). The age at onset of patients with the ATA/ATA genotype was the lowest among the patients with SS (fig 1, upper). In contrast, that of patients with the ACC/ACC genotype was the highest among patients with SS. The age at onset of ACC haplotype non-carriers was significantly lower than that of ACC haplotype carriers $(\mathrm{p}<0.001)$. A younger age at onset of SS was likely to be positively related to the ATA haplotype and negatively to the ACC haplotype (fig 1, lower). The frequency of ACC haplotype was decreased in HTLV-I seropositive patients with SS compared with seronegative patients with SS, though the difference was not significant (data not shown). We failed to detect any association between ILl0 gene polymorphisms and any of the following parameters:

Table 1 Individual IL 10 genotypes, haplotype carrier rates, and haplotype frequencies in healthy controls and patients with Siögren's syndrome (SS)

\begin{tabular}{|c|c|c|c|c|c|c|}
\hline & \multirow{2}{*}{$\begin{array}{l}\text { Siögren's } \\
\text { syndrome } \\
\text { (n=47) }\end{array}$} & \multirow[b]{2}{*}{$\begin{array}{l}\text { Healthy controls } \\
(n=107)\end{array}$} & \multirow[b]{2}{*}{$\chi^{2}, p$ value } & \multicolumn{2}{|c|}{ Sjögren's syndrome } & \multirow[b]{2}{*}{$\chi^{2}, p$ value } \\
\hline & & & & $\begin{array}{l}\lg G \geqslant 15 g / l \\
(n=28)\end{array}$ & $\begin{array}{l}\lg G<15 \mathrm{~g} / \mathrm{l} \\
(\mathrm{n}=9)\end{array}$ & \\
\hline \multicolumn{7}{|c|}{ Genotype No (\%) } \\
\hline ACC/ACC & $1(2)$ & $6(6)$ & $0.313^{*}$ & $0(0)$ & $1(11)$ & $0.243^{*}$ \\
\hline ACC/ATA & $14(30)$ & $45(42)$ & 0.149 & $6(21)$ & $4(44)$ & $0.959^{*}$ \\
\hline ATA/ATA & $24(51)$ & $42(39)$ & 0.173 & $17(61)$ & $1(11)$ & $0.012^{*}$ \\
\hline $\mathrm{ACC} / \mathrm{GCC}$ & $1(2)$ & $4(4)$ & $0.516^{*}$ & $1(2)$ & $4(44)$ & $\overline{0.516^{*}}$ \\
\hline ATA/GCC & $7(15)$ & $10(9)$ & 0.312 & $3(11)$ & $3(33)$ & $0.757^{*}$ \\
\hline GCC/GCC & $0(0)$ & $0(0)$ & & $0(0)$ & $0(0)$ & \\
\hline \multicolumn{7}{|c|}{ Haplotype carrier rate, № (\%) } \\
\hline $\mathrm{ACC}$ carriers & $16(34)$ & $55(51)$ & 0.047 & $7(25)$ & $5(56)$ & $0.100^{*}$ \\
\hline ATA carriers & $45(96)$ & 97 (91) & $\overline{0.230}$ & $26(93)$ & $8(89)$ & $0.578^{*}$ \\
\hline GCC carriers & $8(17)$ & 14 (13) & 0.520 & $4(14)$ & $3(33)$ & $0.955^{*}$ \\
\hline \multicolumn{7}{|c|}{ Haplotype frequency, № (\%) } \\
\hline ACC & $17 / 94(18)$ & $61 / 214(29)$ & 0.053 & $7 / 56(13)$ & $6 / 18(33)$ & $0.988^{*}$ \\
\hline ATA & 69/94 (73) & $139 / 214(65)$ & 0.145 & $43 / 56(77)$ & $9 / 18(50)$ & 0.033 \\
\hline GCC & $8 / 94(9)$ & $14 / 214(7)$ & 0.537 & $4 / 56(7)$ & $3 / 18(17)$ & $\overline{0.385^{*}}$ \\
\hline
\end{tabular}



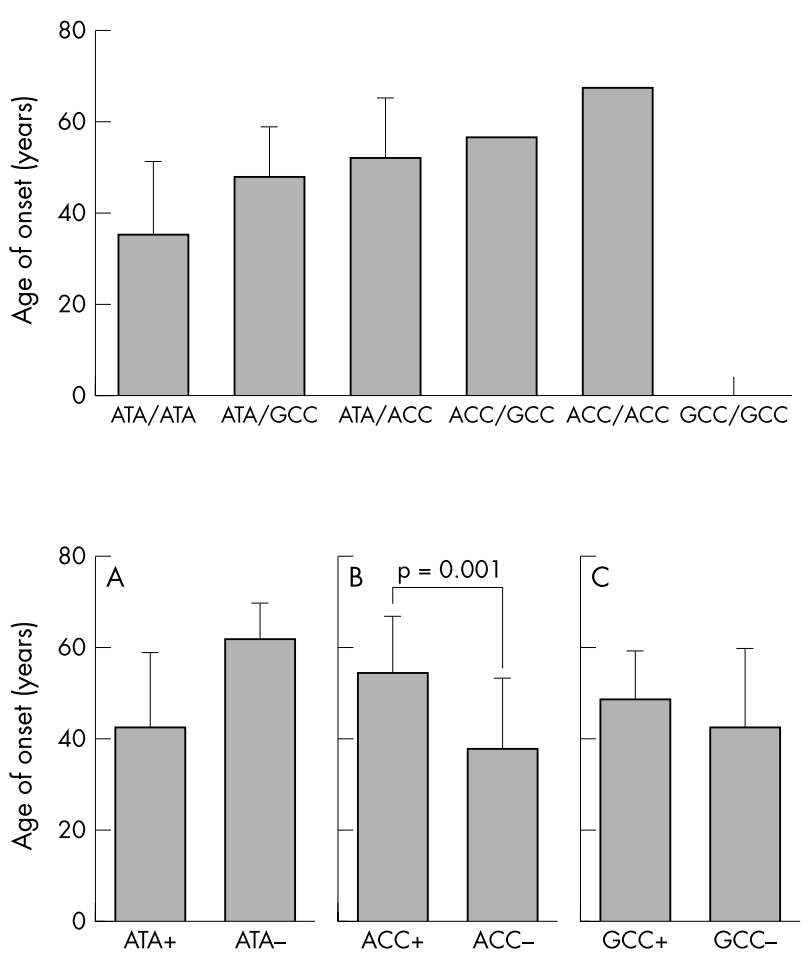

Figure 1 The effect of interleukin 10 (IL10) genotypes (upper part) on age at onset in Japanese patients with primary SS. (Lower part) Age at onset (mean and SD) is shown among the carriers and non-carriers of the IL10 ATA haplotype (panel A), ACC haplotype (panel B), and GCC haplotype (panel C), respectively.

sex, the presence of sicca symptoms, Schirmer test, salivary flow, or anti-Ro and anti-La antibodies (data not shown).

Our results suggested that the presence of the ATA haplotype and the absence of the ACC haplotype of the IL10 gene were associated with an increased sucseptibility to primary SS. Moreover, IL10 gene promoter region polymorphism affected the age at onset of SS, and supported evidence that variation in the age at onset of SS was genetically determined. We also clarified the association between IL10 gene polymorphisms and serum IgG levels. Brennan et al reported that a raised IgG level had a high specificity and high positive predictive value for SS. ${ }^{10}$ IL10 gene polymorphism may become a useful predictor of SS.

\section{Authors' affiliations \\ T Origuchi, Nagasaki University School of Health Sciences, Japan E Kawasaki, A Ide, M Kamachi, F Tanaka, H Ida, A Kawakami, K Migita, K Eguchi, First Department of Internal Medicine, Graduate \\ School of Biochemical Sciences, Nagasaki University, Japan}

Correspondence to: Tomoki Origuchi, Nagasaki University School of Health Sciences, 1-7-1 Sakamoto, Nagasaki, 852-8520, Japan; origuchi@net.nagasaki-u.ac.jp

Accepted 5 March 2003

\section{REFERENCES}

1 Nakken B, Jonsson R, Bolstad Al. Polymorphisms of the Ro52 gene associated with anti-Ro 52-kd autoantibodies in patients with primary Sjögren's syndrome. Arthritis Rheum 2001;44:638-46.

2 Perrier S, Coussediere C, Dubost JJ, Albuisson E, Sauvezie B. IL-1 receptor antagonist (IL-1RA) gene polymorphism in Sjögren's syndrome and rheumatoid arthritis. Clin Immunol Immunopathol 1998:87:309-13.

3 Hulkkonen J, Pertovaara M, Antonen J, Pasternack A, Hurme M. Elevated interleukin- 6 plasma levels are regulated by the promoter region polymorphism of the IL6 gene in primary Siögren's syndrome and correlate with the clinical manifestations of the disease. Rheumatology (Oxford) $2001 ; 40: 656-61$

4 Bolstad Al, Wargelius A, Nakken B, Haga HJ, Jonsson R. Fas and Fas ligand gene polymorphisms in primary Sjögren's syndrome. J Rheumatol 2000;27:2397-405.

5 Mullighan CG, Heatley S, Bardy PG, Lester S, Rischmueller M, Gordon TP. Lack of association between mannose-binding lectin gene polymorphisms and primary Sïgren's syndrome. Arthritis Rheum 2000:43:2851-2.

6 Wang Z, Morinobu A, Kanagawa S, Kumagai S. Polymorphisms of the mannose binding lectin gene in patients with Sjögren's syndrome. Ann Rheum Dis 2001;60:483-6.

7 Kumagai S, Kanagawa S, Morinobu A, Takada M, Nakamura K Sugai S, et al. Association of a new allele of the TAP2 gene, TAP2*Bky2 (Val577), with susceptibility to Siögren's syndrome. Arthritis Rheum 1997;40:1685-92.

8 Morinobu A, Kanagawa S, Koshiba M, Sugai S, Kumagai S. Association of the glutathione S-transferase MI homozygous null genotype with susceptibility to Siögren's syndrome in Japanese individuals. Arthritis Rheum 1999;42:2612-15.

9 Hulkkonen J, Pertovaara M, Antonen J, Lahdenpohia N, Pasternack A Hurme M. Genetic association between interleukin-10 promoter region polymorphisms and primary Sjögren's syndrome. Arthritis Rheum 2001;44:176-9.

10 Brennan M T, Sankar V, Leakan R A, Kleiner D, Atkinson J C, Wilkinson W E et al. Risk factors for positive minor salivary gland biopsy findings in Sjögren's syndrome and dry mouth patients. Arthritis Rheum 2002;47:189-95.

\section{Cigarette smoking, TB, and TNF inhibitors}

\section{J Bieber, A Kavanaugh}

A ccompanying the tremendous excitement about the introduction of TNF inhibitors into the clinic has been caution about potential adverse events that may be associated with the use of these potent immunomodulators. Increased susceptibility to certain infections, particularly Mycobacterium tuberculosis (TB), has been a particular concern. ${ }^{1}$ Data from animal studies suggest that TNF has a central role in host defence against $\mathrm{TB}$, in part related to effective granuloma formation. ${ }^{2}$ For infliximab, 277 cases of TB had been reported world wide through August 2002 among more than 365000 patients treated. Interestingly, although about $75 \%$ of infliximab use has been in the United States, more than two thirds of the reported TB cases were from outside the USA, mainly from the European Union. Part of the reason for this discrepancy may relate to a higher incidence of latent TB infection in the EU. However, we suggest that cigarette smoking may also be a relevant factor. In 2000, just over $23 \%$ of adults in the USA were current cigarette smokers, compared with about 30\% of European adults (http://www. cdc.gov/tobacco; http://www.cisid.who.dk/tobacco-accessed 
$29 / 8 / 03)$. It has recently been shown that acetylcholine can inhibit the release of macrophage $\mathrm{TNF} \alpha$ and attenuate inflammatory responses. ${ }^{3}$ The inhibition is through a posttranscriptional mechanism that is dependent on the $\alpha 7$ subunit of the nicotinic acetylcholine receptor on human macrophages. Nicotine is a potent agonist of these $\alpha 7$ receptors, providing some explanation for the immunomodulatory effects of cigarette smoking in conditions such as ulcerative colitis. ${ }^{4}$ Interestingly, an association between tobacco smoking and TB has been noted in patients from southern India, with an odds ratio among smokers of 2.48 (95\% confidence interval 1.42 to 4.37$).^{5}$ Unfortunately, information on smoking histories among patients with RA and TB treated with TNF inhibitors is not readily available from pharmacovigilance data. Among the varied deleterious effects cigarette smoking has on pulmonary funtion, it can damage the respiratory mucosa, thereby impairing host resistance to infection. Interestingly, it has recently been noted in a trial of anakinra that patients with underlying pulmonary disease seemed to be at a particular risk for developing pneumonia. ${ }^{6}$ Therefore, rheumatologists ought to elicit a smoking history and advise stopping smoking among patients with RA, particularly those being considered for treatment with TNF inhibitors.
Authors' affiliations

J Bieber, A Kavanaugh, Center for Innovative Therapy, Division of Rheumatology, Allergy and Immunology, UCSD School of Medicine, La Jolla, California 92093-0943, USA

Correspondence to: Dr A Kavanaugh; akavanaugh@ucsd.edu

Accepted 10 July 2003

\section{REFERENCES}

1 Keane J, Gershon S, Wise RP, Mirabile-Levens E, Kasznica J Schwieterman WD, et al. Tuberculosis associated with infliximab, a tumor necrosis factor $\alpha$-neutralizing agent. N Engl J Med 2001;345:1098-104.

2 Mohan VP, Scanga CA, Yu K, Scott HM, Tanaka KE, Tsang E, et al. Effects of tumor necrosis factor alpha on host immune response in chronic persistent tuberculosis: Possible role for limiting pathology. Infection Immunity 2001;69:1847-55.

3 Wang H, Yu M, Ochani M, Amella CA, Tanovic M, Susarla S, et al. Nicotinic acetylcholine receptor $\alpha 7$ subunit is an essential regulator of inflammation. Nature 2003;421:384-8.

4 Floto RA, Smith KGC. The vagus nerve, macrophages, and nicotine. Lancet 2003;361:1069-70.

5 Kolappan C, Gopi PG. Tobacco smoking and pulmonary tuberculosis. Thorax 2002;57:964-6.

6 Fleischmann RM, Schechtman J, Bennett R, Handel ML, Burmester GR, Tesser J, et al. Anakinra, a recombinant human interleukin-1 receptor antagonist ( $r$ metHulL-1 ra), in patients with rheumatoid arthritis. Arthritis Rheum 2003:48:927-34.

\section{Large synovial cysts originating from the sternoclavicular joints in a patient with rheumatoid arthritis}

\section{A P Andonopoulos, N Meimaris, G Yiannopoulos, V Pastromas, P Dimopoulos}

Ann Rheum Dis 2003;62:1119-1120

S ynovial cysts in rheumatoid arthritis (RA), most common in the popliteal fossa, ${ }^{12}$ have also been described in proximity to several other rheumatoid joints, ${ }^{3-9}$ but never the sternoclavicular joints.

\section{CASE REPORT}

We here describe, for the first time, the development of unusually large synovial cysts, from the disproportionately small sternoclavicular joints, in a 58 year old man, with a 27 year history of severe, seropositive, erosive, destructive, deforming, nodular RA. Over the years he had been treated, albeit erratically, with several disease modifying antirheumatic drugs (DMARDs), but he had been poorly followed up.

Seven months ago, while receiving D-penicillamine $500 \mathrm{mg} /$ day and methylprednisolone $2 \mathrm{mg} /$ day, he presented with a $10 \mathrm{~cm}$ long and $5 \mathrm{~cm}$ thick, fluctuant, non-tender, sausage-like mass over the right clavicle, and a smaller one, about $5 \mathrm{~cm}$ long over the left clavicle, developed gradually over one month. Routine haematology and biochemistry were normal. A purified protein derivative (PPD) skin test was negative.

A chest computed tomomographic (CT) scan (fig lA) showed sclerosis and subchondral and marginal erosions in the manubriosternal and both sternoclavicular and first costosternal articulations. The posterior sternal surface was largely eroded, and the cancellous portion transformed to a smooth walled cavity, filled up with soft tissue. The overlying anterior thoracic wall soft tissues contained several cystic lesions, $1-6 \mathrm{~cm}$ in diameter, arranged parallel to the two lateral sternal borders. The four upper costovertebral joints (not shown) were similarly affected. Paracentesis of the right mass yielded a turbulent dark yellow fluid, with white blood cells (WBCs) $40.5 \times 10^{9} / 1 \quad(82 \%$ polymorphonuclear cells (PMNs)), sugar of $80 \mathrm{mg} / \mathrm{l}$ and no malignant cells. Direct stains and cultures for common and acid fast bacteria and fungi were negative. An open biopsy of the wall of the mass on the right showed granulomatous fibrous tissue, with no evidence of malignancy and negative culture. After a repeat paracentesis with similar results, three months later, an injection, with a long acting corticosteroid preparation, of both masses was performed. Two months later, the left mass disappeared and that on the right was significantly reduced, confirmed by a second CT scan (fig 1B). This scan disclosed further excessive destruction of the left glenohumeral joint and a $6 \mathrm{~cm}$ synovial cyst, just anteroinferior to that, under the left upper thoracic muscles. A magnetic resonance imaging (MRI) scan confirmed, additionally, that the cysts contained only fluid, whereas their walls showed enhancement after the administration of paramagnetic medium, suggesting active inflammation (figures not shown). Furthermore, MRI showed that the soft tissue eroding the upper part of the sternum had broken into the anterior mediastinum, in close contact with the anterior pleura. Although the whole area was examined meticulously by MRI, in more than two planes, no communication of the cysts with the proximal or remote joints was demonstrated.

\section{DISCUSSION}

The synovial origin of the described lesions was strongly supported by (a) their cystic nature confirmed by CT and 

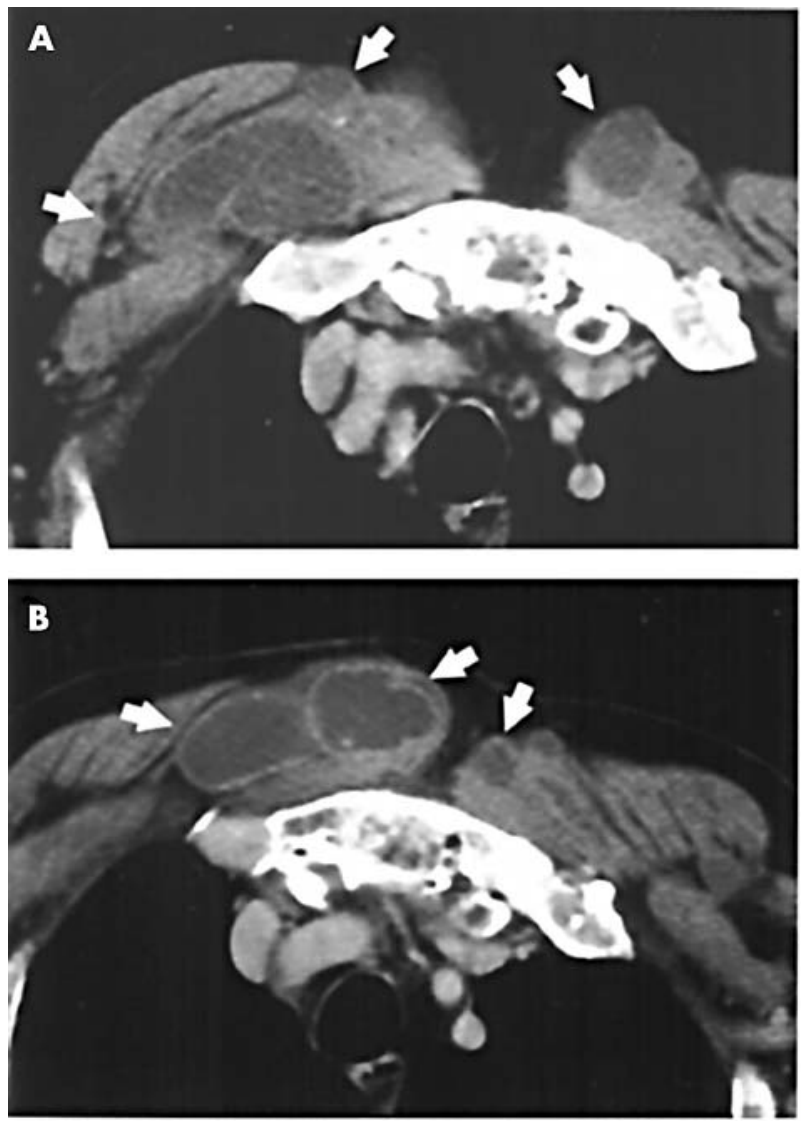

Figure 1 First (A) and second (B) CT scans through the manubriosternal articulation, show several cysts (arrows) with thin, contrast enhanced walls, lying under both major pectoralis muscles, mainly on the right. The number and size of the cysts are decreased in (B).

MRI; $(b)$ the inflammatory character of the fluid they contained; $(c)$ the exclusion of any infectious or malignant process; $(d)$ the biopsy of the cystic wall, typical for synovial cyst; (e) the favourable response to the local steroid injection.
Interestingly, imaging did not succeed in demonstrating any communication between the cysts and the sternoclavicular or the upper costosternal joints, a feature which even arthrography may not disclose. Nevertheless, the arrangement of the cysts along the sternal borders, and their close proximity to the severely affected sternal joints, led us to presume that they originated in the latter.

This unusual case emphasises the possibility of synovial cyst formation from any inflamed rheumatoid joint, no matter how small it may be, and the fact that such presentations may appear in very atypical locations, posing important and sometimes difficult diagnostic problems.

\section{Authors' affiliations}

A P Andonopoulos, N Meimaris, G Yiannopoulos, Department of Medicine, Division of Rheumatology, University of Patras School of Medicine, Patras, Greece

V Pastromas, P Dimopoulos, Department of Radiology, University of Patras School of Medicine, Patras, Greece

Correspondence to: Professor A P Andonopoulos, Division of Rheumatology, University of Patras School of Medicine, 26500 Rio, Patras, Greece; andandon@med.upatras.gr

Accepted 11 March 2003

\section{REFERENCES}

1 Swett HA, Jaffe RB, Mclff EB. Popliteal cysts: Presentation as thrombophlebitis. Radiology 1975;115:613-15.

2 Andonopoulos AP, Yarmenitis S, Sfountouris H, Siamplis D, Zervas C, Bounas A. Baker's cyst in rheumatoid arthritis: an ultrasonographic study with a high resolution technique. Clin Exp Rheumatol 1995;13:633-6.

3 Meurman KOA, Luppi A, Turunen MJ. A giant retrofemoral Baker's cyst. Br J Radiol 1978;51:919-20.

4 Coulton BL, Ropert A. Massive extension of the suprapatellar pouch into the thigh tissues in rheumatoid disease. Ann Rheum Dis 1986;45:174-5.

5 Chaiamnuay P, Davis P. An unusual case of inguinal swelling. Arthritis Rheum 1984;27:239-40

6 Bienenstock H. Rheumatoid plantar synovial cysts. Ann Rheum Dis 1975:34:98-9.

7 Ehrlich GE, Guttmann GG. Valvular mechanisms in antecubital cysts of rheumatoid arthritis. Arthritis Rheum 1973;16:259-64.

8 Bowerman JW, Muhletaler C. Arthrography of rheumatoid synovial cysts of the knee and wrist. J Canad Assoc Radiol 1973:24:24-32.

9 Sharon E, Vieux U, Seckler SG. Giant synovial cyst of the shoulder and perforation of the nasal septum in (a patient with) rheumatoid arthritis. M Sinai J Med 1978;45:103-5. 